\title{
Search Software for Ustadz, Categories: Preacher, Qari and Qariah in Palembang Using an Android-Based Usability Approach
}

\author{
M. Rudi Sanjaya ${ }^{1, *}$ Yadi Utama ${ }^{2}$ Dedy Kurniawan ${ }^{2}$ Ariansyah Saputra ${ }^{3}$ Novita \\ Sari $^{4}$ Rahma Destriani ${ }^{4}$ Muhammad Raihan Udda Rahmany ${ }^{4}$
}

\author{
${ }^{1}$ Internet Programming Laboratory Department of Computer Engineering, Faculty of Computer Science, Universitas \\ Sriwijaya, Indonesia \\ ${ }^{2}$ Department of Computer Engineering, Faculty of Computer Science, Universitas Sriwijaya, Indonesia \\ ${ }^{3}$ Department of Computer Engineering, Politeknik Negeri Sriwijaya, Indonesia \\ ${ }^{4}$ Student Department of Computer Engineering, Faculty of Computer Science, Universitas Sriwijaya, Indonesia \\ *Corresponding author. Email: m.rudi.sjy@ilkom.unsri.ac.id
}

\begin{abstract}
Each Muslim conducts preaching activities and Al-Qur'an Qari, Qariah in Islam in various Islamic activities, but still challenging to determine its location, especially in Palembang itself. There are many mosques which are challenging to get information about the location of the Preaching, location of Qari and Qariah because it is still very minimal address information or many who do not know so, it is often the difficulty in finding locations such as the location of Preaching, Al-Qur'an both Ustadz. The purpose of this research is to create software to facilitate searching preaching location and reading the Al-Qur'an Qari and Qariah both Ustadz. The benefits of this research are to produce mobile software where the public can obtain information on the location of Da'wah (lecturer) ultimately, Qari and Qariah by using Mobile information media such as Smartphone. The level measurement of satisfaction uses usability, where its research data using a questionnaire consisting of 49 respondents showed valid data with test results:: $\mathrm{df}=\mathrm{n}-2=49-2=$ 47 , rcount $=0,2816$ condition of valid : rcount $>$ rtable, lt 1 (learnability) : 0,851 >0,2816 (valid), lt 2 (learnability): $0,822>0,2816$ (valid), lt 3 (learnability) : 0,721>0,2816 (valid), lt 4 (learnability) : 0,520>0,2816 (valid), eff 1(efficiency) : 0,743>0,2816 (valid), eff 2 ( efficiency) : 0,559>0,2816 (valid), eff 3 ( efficiency) : $0,636>0,2816$ (valid), eff 4 ( efficiency) : 0,499 > 0,2816 (valid), me 1 (memorability) : 0,705> 0,2816 (valid), me 2: (memorability) : 0,800>0,2816 (valid), me $3:$ (memorability) : $0,833>0,2816$ (valid), me $4:$ (memorability) : 0,558>0,2816 (valid), er $1:$ (few errors) $0,649>0,2816$ (valid), er $2:$ (few errors) $0,774>0,2816$ (valid), er $3:$ (few errors) $0,676>$ 0,2816 (valid), er $4:$ (few errors) $0,614>0,2816$ (valid), st $1:$ (satisfaction) 0,699>0,2816 (valid), st $2:$ (satisfaction) $0,650>0,2816$ (valid), st $3:$ (satisfaction) $0,672>0,2816$ (valid), st $4:$ (satisfaction) $0,614>0,2816$ (valid) meanwhile for testing the reliability of all data obtained reliable.
\end{abstract}

Keywords: Search sofwere, preaching, andAndroid Based Usability

\section{INTRODUCTION}

In Islamic da'wah teachings, qari and qariah is defined as inviting and calling on Muslims to carry out the commands of Allah SWT and comply with all forms of Allah SWT's prohibitions or all activities are to call, invite and also summon people to believe and obey Allah SWT according to the line of aqidah morals in teachings, law and morals in Islam. Preaching activities and reading Al-Qur'an Qari and Qariah in Islam are conducted by each Muslim in various Islamic activities, but still challenging to determine its location, especially in Palembang itself. There are many mosques which are challenging to get information about the Preaching location, location of Qari and Qariah because it is still very minimal address information or many who do not know so, it is often the difficulty in finding locations such as the location of the preaching, Al-Qur'an both Ustadz. The purpose of this research is to create software to facilitate searching preaching location and reading the Al-Qur'an Qari and Qariah both Ustadz [1].

In Palembang, it is still challenging to find detailed information about information or information to look for Ustadz in Palembang. Even though in previous 
research, an integrated system of preacher scheduling management has been made in mosques that are recorded in da'wah institutions, this system lacks flexibility and complete system, and the system that has been created only searches for preachers for preaching regarding preaching, so it is necessary For making it easier to find the Ustadz, it is needed to use a mobile phone technology.

The development of smartphones is currently being used very quickly, not only as a means of communication but also used, one of which is that cellphones are one of the most sophisticated technological tools or can be called smartphones [2]. Where the advantages of an android device that is used or functioned to facilitate the users in obtaining or obtaining detailed or detailed information or information about a tourist location with several facilities around a tourist attraction in a full and details later. This can be one of the main tools based on interactive mobile [3]. Public facilities are one that is in the Bekasi area, which is located in East Bekasi, which is needed by the community, where one of the places used is a place of worship. Information about places of worship that is needed and used by the community, where they can see well the places of worship and directions or locations to get to the destination, so that in making this mobile application in the form of Augmented Reality it is used to locate places of worship in Bekasi Timur which consists of several mosques as well as churches with one using a platform to support the application [4].

Technology is a form of process to increase the added value or plus value so that an added value can be created in one of the areas of da'wah, and a dakwah application is built or designed using one of them is android. Respondents in the research are students and religious teachers in Islamic boarding schools in the region. Mojotengah sub-district, Wonosobo Regency. These results are obtained from a questionnaire that has met the criteria for one of the usability criteria or its usability [1].

Al-Quran is the holy book of Muslims (Islam) which consists of 114 letters, 30 juz and 6236 verses. Where it is not easy if you want to find information or information about a topic discussed in the Al-Quran, and it will take a long time to find the topic you are looking for is done manually without having an application based on Smartphone technology. For that, we need one of them, namely an application that can accommodate or provide information the needs of each user or user for an application that is easy to carry and can be used anytime and anywhere effectively and efficiently. One of the Android-based applications for searching the letters of Al-Quran or verses of Al-Quran works quickly in finding words needed by the users or users using a smartphone [5].

If someone wants to study, he has to come to the houses of the teachers in science assemblies around their house, and if it is a long-distance, then application is needed. Laziness will come if someone has got a saturation point in finding a teacher to learn about Islam due to the difficulty of finding teachers around the house so that an application for searching Ustaz for the City of DKI Jakarta and its surroundings is designed using Android with the Haversine Formula algorithm. It is hoped that this system can help with detailed info or information. This application is designed using the UML method [6].

Technology for various conveniences. One of them is the Kalbis Institute Library that has used or utilizes computer technology and an information system about searching for book catalogues using the Senayan Library Management System or SLiMS which suggests that one of the Free Open Source Software uses the web to build a library system [7]. Unified modelling language (UML) is one of the standards model languages in developing systems in software, or modelling applications in UML which is essential in using or explaining an aspect of system functionality, one of which is used case modelling, which is described using textually in the form of use. The case scenario is used to describe the interactions or relationships that occur between actors and the system [8].

In this study, to build software using usability approach, usability has five attributes, namely easy to learn and use (learnability), efficient to use (efficiency), easy to remember (memorability), few errors (few errors) and subjective satisfaction (satisfaction) [9]. Where it is difficult to search for the category of preacher, qari and qariah manually and not computerized in the city of Palembang, so the need for an Android-based software is used to make it easier to find info or information about preacher, qari and qariah

\section{OVERVIEW}

\subsection{Software}

Software is anything for formatted data, and whether stored in digital form or including a computer program and documentation, as well as various information that can or can be read and also written by a computer, it can also be said that the software can only be seen but not can be held.

Software is an isolated computer program, with software documentation (P/L) which consists of requirements documentation, design models, and user manuals, where a computer program, without being isolated from its documentation cannot be said to be a software [10].

\subsection{Da'wah}

Da'wah in Islam is inviting and calling for Muslims to carry out commandments of Allah SWT and stay away from all forms of the prohibition of Allah or any activity or any other activity is to call, invite and summon people to believe and fear Allah SWT according to the lines of both aqidah morals, hint and morality in Islamic teachings. However, dakwah is one of the 
responsibilities of every individual who embraces Islam. The submission of Dakwah was carried out or pioneered by the Prophets, apostles and then forwarded by friends, to the scholars and Muslim society now. Various media for the delivery of Da'wah is used whether the medium of communication orally or not orally. [1]

\subsection{Qari and Qariah}

Qari is a term given to a man who reads Al-Quran and chants the recitation of Al-Quran to obey the correct rules, doing everything commanded by Allah SWT and away from what is forbidden by Allah SWT and then Qariah a term given to a woman who reads Al-Quran and chants the recitation of Al-Quran to obey the correct rules, doing everything commanded by Allah SWT and away from what is forbidden by Allah SWT.

\subsection{Concept of Android Software}

Android sotware which consists of operating system, middleware and application. Where Android also provides an open platform for those to expand and to create their applications.

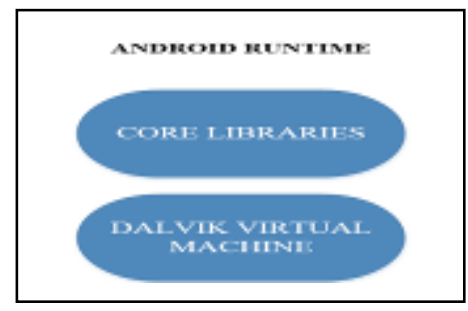

Figure 1 Layer of Android Runtime

An Android is said to be a complete platform, whether it is from the side of its operating system, applications and development tools, the market is an Android application, and to support a very high level of open source community around the world, so that Android continues to multiply, both in terms of technology and in terms of equipment in the world. The following will be spelled out each layer of the Android system layer, figure. 2 under IIS all the layers of the Android Runtime. In the figure 1 is a key component of Androidbased located at a runtime section called Dalvik Virtual Machine (DVM). Where Dalvik is a virtual machine process on the Android-based operating system. Dalvik IE software to run an application on an Android device.

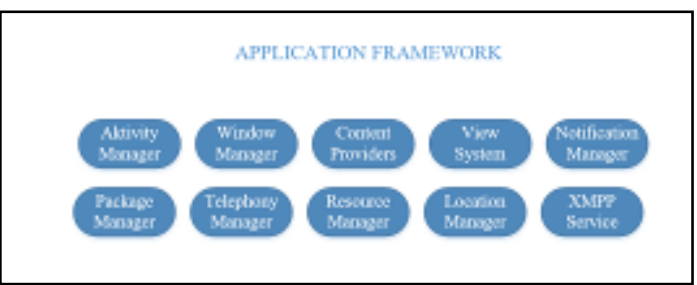

Figure 2 Layer of Application Framework Android
Figure 2 above is all the layers of an Android Application Framework. This section of Android's Application Framework layer provides multiple layer services in the form of Java classes.

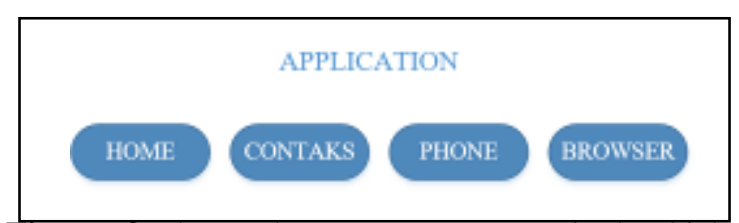

Figure 3 above there are some standard which has provided by Android. The top layer of Android software is application layer.

\section{RESEARCH METHODOLOGY}

At the data collection stage, the methods used are as follows: Observation Methods Make observations to obtain data for the software that has been built then the software is tested with usability testing.

\subsection{Data Collection}

The data collection of this research is disseminated through a questionnaire and shows the tools that have been made, used as the research object are ustadz with the category of preacher, qari and qariah in Palembang.

\subsection{Analysis Data}

This research consists of 49 respondents consisting Ustaz in the area of Palembang to conduct testing using the questionnaire disseminated Ustaz, the software in the wake using the Android programming language tool is Android Studio after the wake of the software in the test using usability measurement consisting of validity and reliabilty testing. The data is managed using usability measurements, and then the data is processed obtained through a questionnaire using the SPSS 22 application.

\subsection{Software Development Methods}

The development of this software development method is the Prototype Model. Here is the Prototype Model 


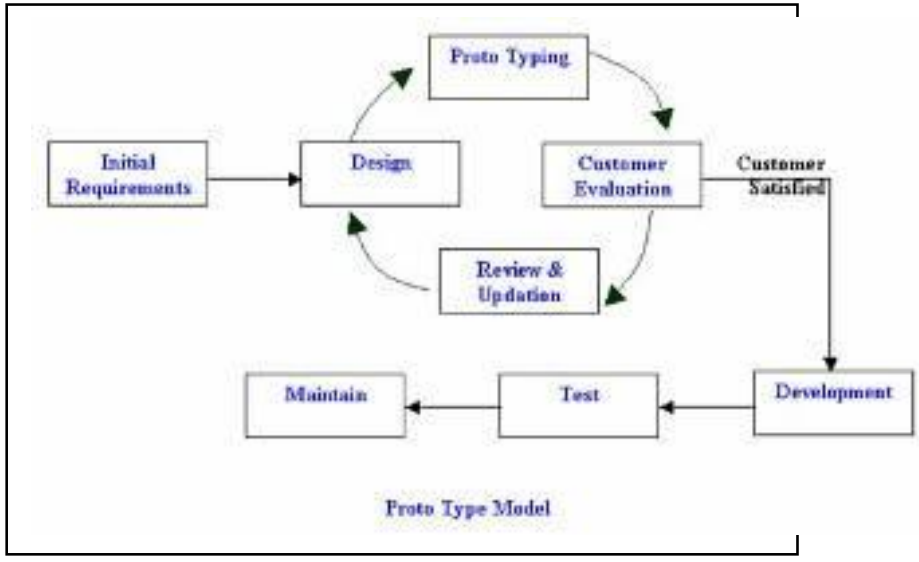

Figure 4. Prototype Model

The stages in Prototyping are as follows.:

1. Collection of needs is Customers and developers together define the format of the entire software, identify all requirements, and an outline of the system to be made.

2. Build Prototyping

Build Prototyping by making temporary designs that focus on serving customers (for example, by creating input and output formats).

3. Evaluation of prototyping

This evaluation is carried out by the customer, whether the Prototyping that has been built is in accordance with the customer's wishes. Otherwise, Prototyping is revised by repeating.

4. Encoding the system

In this stage, the Prototyping that has been agreed upon is translated into the appropriate programming language.

5. Test the system

After the system has become a ready-to-use software, it must be tested before use. This test is carried out by usability testing

6. System Evaluation

Customers evaluate whether the finished system is as expected.

7. Using the system

Software that customers have tested and accepted is ready to use.

\subsection{Usability Measurement}

Assessing usability is an essential parameter in measuring the efficiency of the software or information systems. Usability refers to performance, customer loyalty and effectiveness. A high degree of usability is typically correlated with the users' success and high use of the system/software to assist their activities. Systems with low levels of usability are typically left to the user.

Various parameters and measurement devices can measure usability.[12] Usability measurement has five attributes, such as learnability, efficiency, ırability, few error satisfaction. The criteria are as ws: Five Learnability criteria, namely:

1) Learnability as to how quickly users complete simple tasks by using the app first

2) Performance determines how easily users complete usable interface-related tasks after learning how to use the interface

3) Memorability Memorability is how quickly users can recall how to use the program despite failing to communicate for many times. Memorability is the speed with which the device is recalled after users know about using the program.

4) Few errors shows the magnitude of the Code Error

5) Satisfaction describes the desire of users to make it easier for users to walk anywhere

\section{USE CASE ADMIN}

\subsection{Use case Admin}

Admin must log in to manage all data consisting of data preaching, Qari and Qariah , below explains the admin use case.

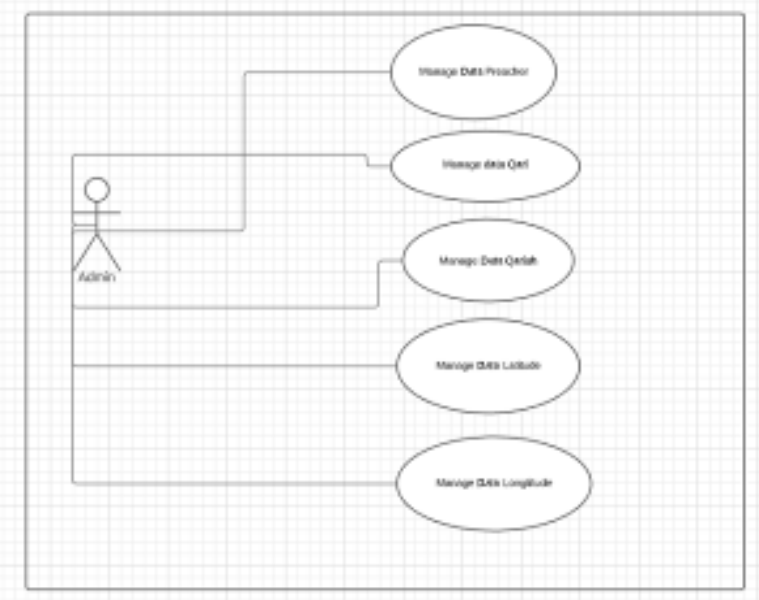

Figure 5. Use case Admin

Figure 4 explains the use Case admin, where the admin manages and accesses all the data for the user, where the user can update all data with the preaching, Qari and Qariah categories. 


\subsection{Use case User}

The figure below explains Use case user:

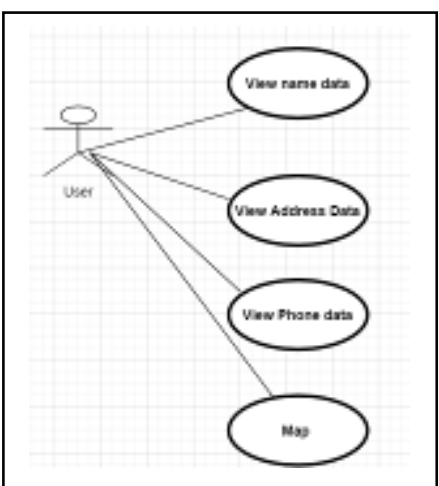

Figure 6. Use case User

Figure 6. Use case can only use data after it has been sent by the admin, which consists of seeing the name, address, telephone, and route to make it easier to find the ustadz.

\subsection{Class Diagram}

This image below explains class diagram of Ustadz search software for preaching, Qari and Qariah categories.

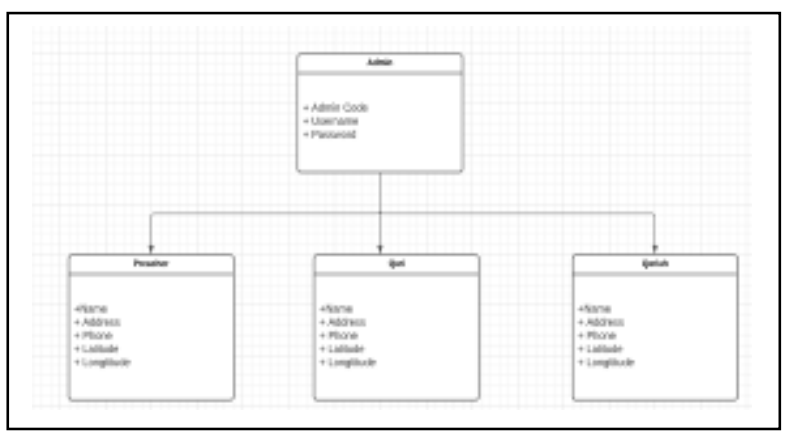

Figure 7. Class diagram

Figure 7. explains class diagram which consists of admin, where the admin consists of admin code, username and password, to give an accent consisting of preaching, Qari and Qariah consisting of name, address, telephone number, latitude and longitude

\section{RESULTS}

\subsection{The display of the Android based software}

Below is the display of the Android based software

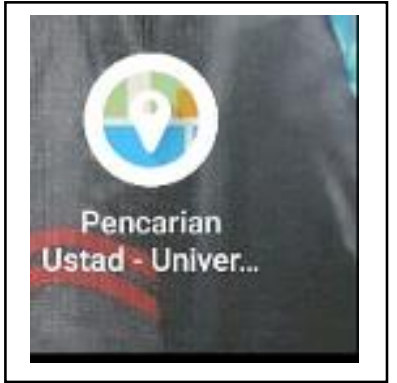

Figure 8. Display of Android Software

Figure 8 explains ustaz search software based on Android is already installed on the smartphone, and ready to use by the user to view information completely.

\subsection{Main Menu of Android User Software}

The first display of software menu consists of preaching, qari and qariah.

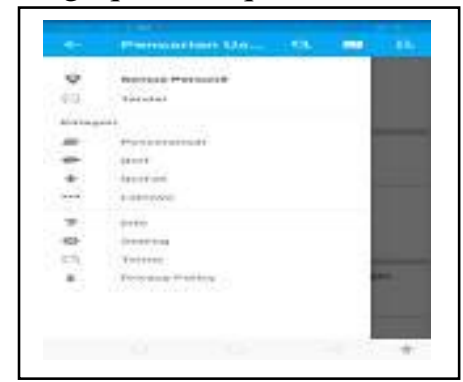

Figure 9. Main menu

In figure 9 explains this software consist of some categories namely preaching, where lecturer category provides information to users for searching Ustadz to get information in detail, as well as qari and qariah

\subsection{The Display of Preacher Software}

This software has categories, consisting of Preacher, Qari and Qariah, below is display of Preacher software :

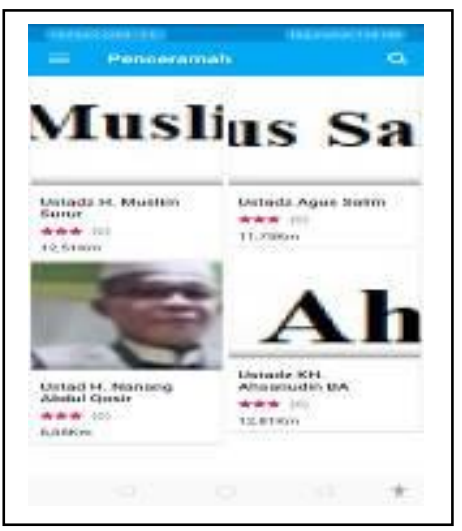

Figure 10. Preaching

Figure 10. explains one of several categories, one of them is Preaching so that users can access Preaching. 


\subsection{Display of Detailed Preaching Menu}

Below explains the software with the preaching category can be seen in this figure 10 :

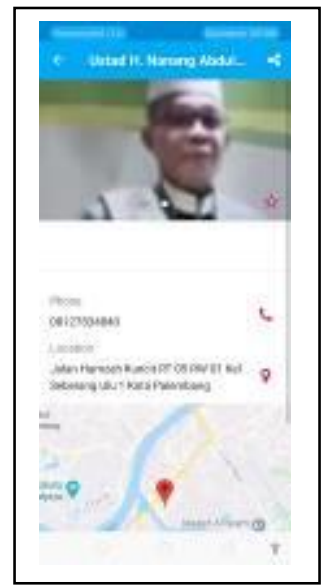

Figure 11. Preaching

In image above is info or information about the Preaching, so that the users can access info or information about the software, especially Preaching.

\subsection{Preaching MAP Route}

Below is a route map regarding android-based software info or information so, users can directly access it via a smartphone, below are the results of the route map for the Preaching category:

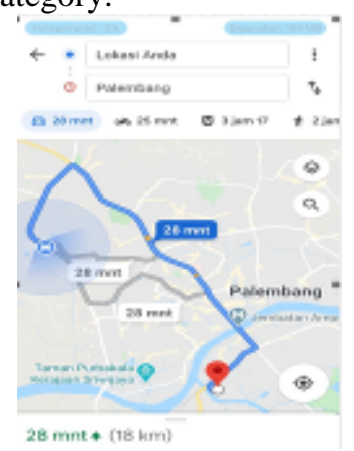

Figure 12. Location of Preaching

Figure 12 explains about searching Ustaz, one of the Preaching categories, so the route will display info or information in detail about the Preaching.

\subsection{Display of Qari}

Below is a display of the software with the qori category:

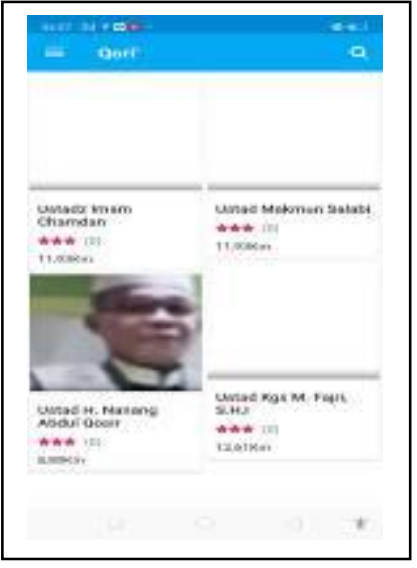

Figure 13. The Software with the Qari Category

Figure 13, explains information about the search for Preaching so the users can get this information, the software makes it easier to search Ustaz with the Qari category.

\subsection{Software Details about Qari}

Below is a display of the software with the reciter category:

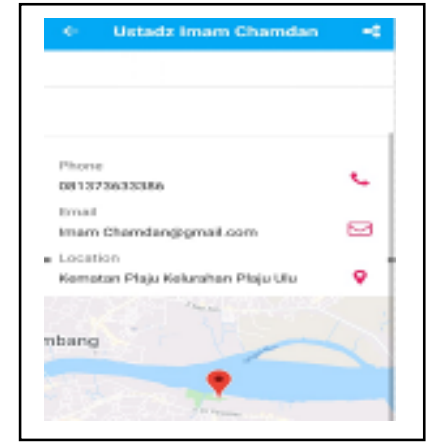

Figure 14. The Software with the Qari Category

Figure 14, Explain the software in qori category, so that it will display complete data about the phone, address, and location, so that making it easier for users to access this information.

\subsection{Route in Qari Category}

Below describes the software with the qori category: 


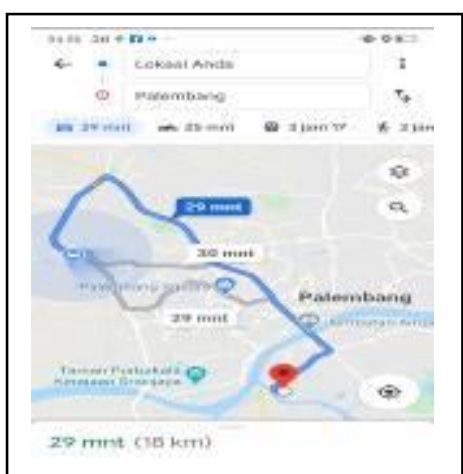

Figure 15. Route Information About Qari

In the image above, it explains the route or detailed information about the search for Ustaz with the reciter category.

\subsection{Display of Ustadz search software for Admin}

Below view for admin:

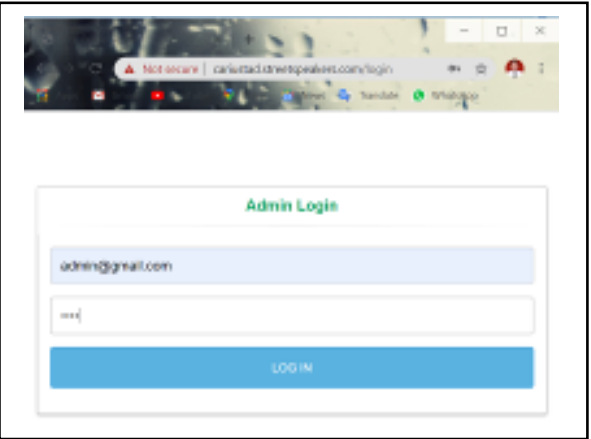

Figure 16. Login Admin

Figure 16 explains admin login, admin can see and manage all data for clerics search in the city of

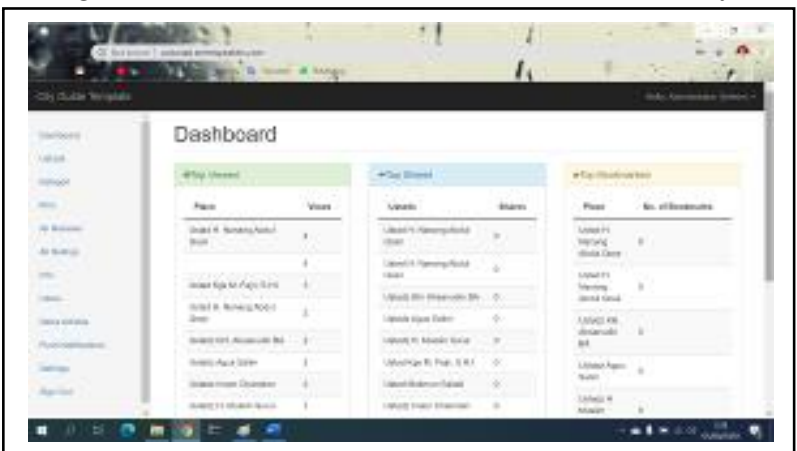

Figure17. Admin Main Menu

Figure 17 explains the admin main menu which consists of several categories, namely Preaching, below are all categories of Preaching, Qori :

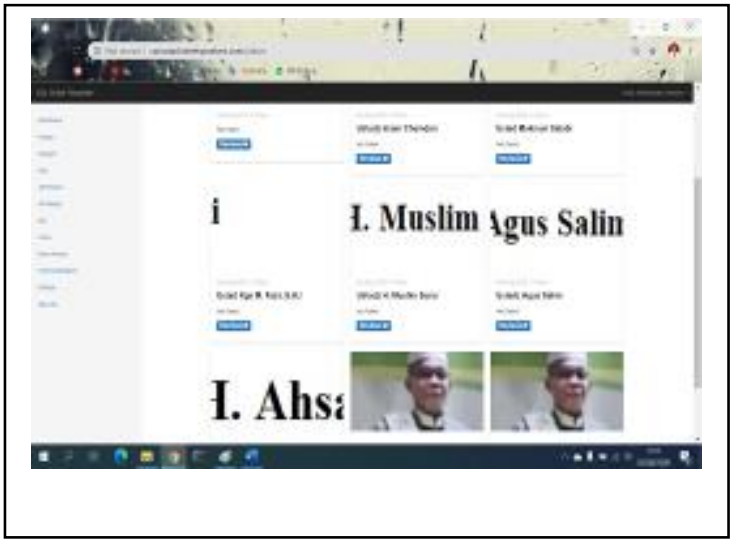

Figure 18. Software with the Preaching, Reciter categories.

Figure 18, it explains that the admin can access data from all categories, both Preaching, Qari and Qariah, and also admin can access to save data, edit and delete, if the data are appropriate, the admin will provide detailed information, and will be accessed on Android, so that users can access the data via smartphone.

\section{USABILITY MEASUREMENT}

\subsection{Respondent Description}

In the research design, it has been explained that the respondents of this study were 49 people.

\subsection{Respondent Data}

Below are the respondent's data for usability measurement managed through the SPSS program

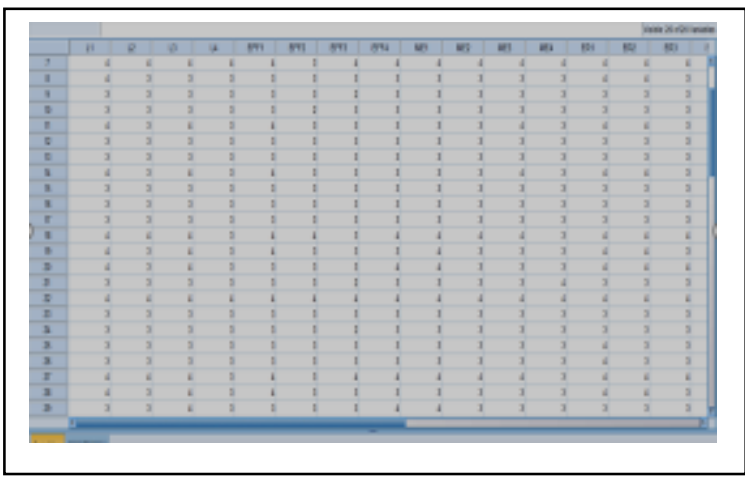

Figure 19. Questionnaire Data Results

Figure 19 describes the results of the questionnaire data obtained through questionnaires and interviews.

\subsection{Validity Test Output}

In image 19 below, it can be concluded that there are 49 respondents as follows: 


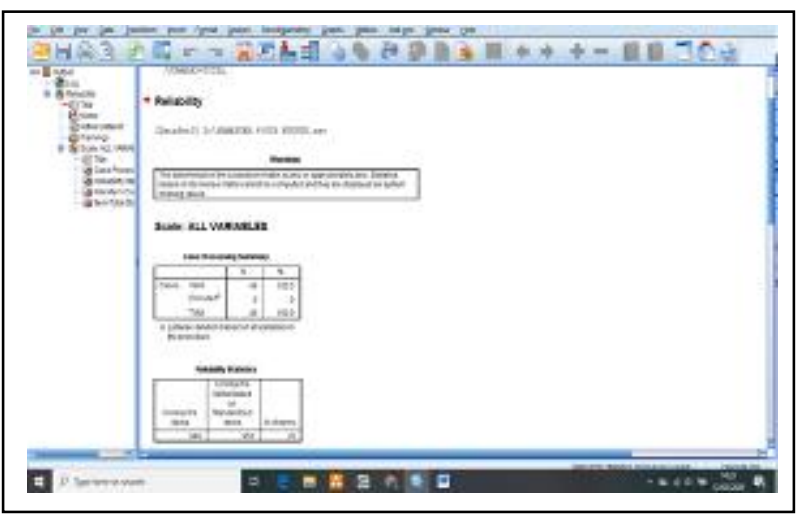

Figure 20. Validity Test Output

Figure 20 results from the output of 49 respondents using the SPSS application

\subsection{Test Validity and Reliability using the Usability Approach}

Validity test is finished by watching the worth of Corrected item-total correlation. If a press release item has $r$ count greater than $r$ table, then the statement is said valid. The entire of respondents is during this survey was 49 .

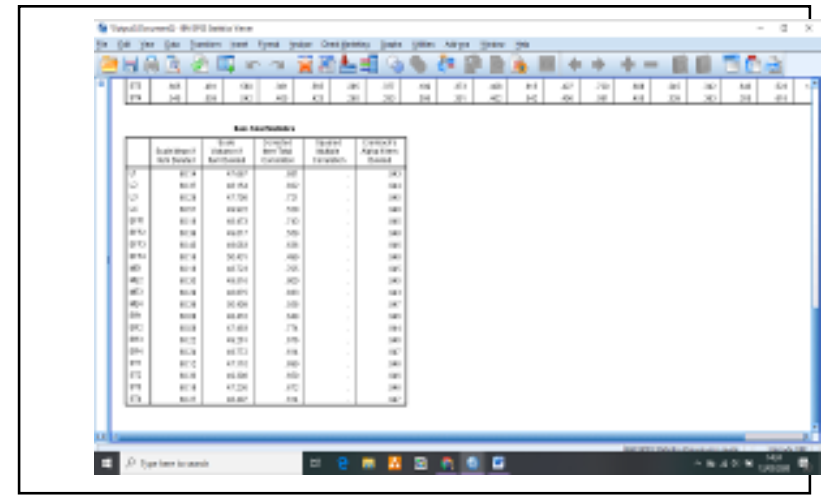

Figure 21. Validity Test Results
In image 21 explains the validity test, specifically:

Df $=\mathrm{N}-2=49-2=47$

$\mathrm{R}$ table $=0,2816$

Valid Requirements: $\mathbf{r}$ count $>\mathbf{r}$ table

LT 1 (Learnability) : 0,851>0,2816 (VALID)

LT 2 (Learnability): 0,822 >0,2816 (VALID)

LT 3 (Learnability) : 0,721 >0,2816 (VALID)

LT 4 (Learnability) : 0,520>0,2816 (VALID)

EFF 1(Efficiency) : 0,743 > 0,2816 (VALID)

EFF 2 ( Efficiency) : 0,559> 0,2816 (VALID)

EFF 3 ( Efficiency) : 0,636>0,2816 (VALID)

EFF 4 ( Efficiency) : 0,499 > 0,2816 (VALID)

ME 1 (Memorability) : 0,705>0,2816 (VALID)

ME 2: (Memorability) : 0,800>0,2816 (VALID)

ME 3 : (Memorability) : 0,833 > 0,2816 (VALID)

ME 4 : (Memorability) : 0,558 >0,2816 (VALID)

ER $1:$ (Few Errors) 0,649> 0,2816 (VALID)

ER $2:$ (Few Errors) 0,774 > 0,2816 (VALID)

ER 3 : (Few Errors) 0,676>0,2816 (VALID)

ER 4 : (Few Errors) 0,614 > 0,2816 (VALID)

ST 1: (Satisfaction) 0,699>0,2816 (VALID)

ST 2 : (Satisfaction) $0,650>0,2816$ (VALID)

ST 3 : (Satisfaction) $0,672>0,2816$ (VALID)

ST 4 : (Satisfaction) 0,614 >0,2816 (VALID)

\subsection{Reliability Testing}

With the same output on the validity, the column is alpha Cronbach. Reliable requirements are: alpha Cronbach > 0.60 Because in the table all variables start with 0.9 , it can be concluded that all data is reliable, it can be seen in table 1 below:

\begin{tabular}{cccc}
\hline Variable & Cronbach's Alpha & Explanation \\
\cline { 4 - 4 } \cline { 3 - 3 } Learnability & .948 & Reliable \\
\hline Efficiency & .946 & Reliable \\
\hline Memorability & .947 & Reliable \\
\hline Few Errors & .944 & Reliable \\
\hline Satisfaction & .946 & Reliable \\
\hline
\end{tabular}

Table 1 shows that the test of reliability with the coefficient of Croncbach's Alpha for all variable data is at an acceptable level above 0.60 .

\section{CONCLUSION}

1) The software is built using the Android programming language, it can be used using a smartphone to get complete information through the cleric search 
software which consists of the categories of Reciter, Preaching

2) With the cleric search software with category mubaligh, qori and qoria can provide complete information about info or information about the location of Reciter, Preaching qoriah and also software with a route (map).

3) The measurement results using usability produce valid values for both validity and reliability where reliability produces reliable data.

4) where its research data using a questionnaire consisting of 49 respondents showed valid data with test results: df $=\mathrm{n}-2=49-2=47$, rcount $=$ 0,2816 condition of valid : rcount > rtable, lt 1 (learnability) : 0,851>0,2816 (valid), it 2 (learnability): $0,822>$ 0,2816 (valid), lt 3 (learnability) : 0,721 $>0,2816$ (valid), it 4 (learnability) : $0,520>0,2816$ (valid), eff 1(efficiency) : $0,743>0,2816$ (valid), eff 2 ( efficiency) : 0,559> 0,2816 (valid), eff 3 ( efficiency) : $0,636>0,2816$ (valid), eff 4 (efficiency) : 0,499 >0,2816 (valid), me 1 (memorability) : 0,705> 0,2816 (valid), me 2:

(memorability) : 0,800>0,2816 (valid), me $3:$ (memorability) : 0,833>0,2816 (valid), me $4:$ (memorability) : 0,558 > 0,2816 (valid), er 1 : (few errors) $0,649>$ 0,2816 (valid), er $2:$ (few errors) 0,774 $>0,2816$ (valid), er $3:$ (few errors) 0,676 $>0,2816$ (valid), er 4 : (few errors) 0,614 $>0,2816$ (valid), st 1 : (satisfaction) $0,699>0,2816$ (valid), st $2:$ (satisfaction) $0,650>0,2816$ (valid), st 3 : (satisfaction) 0,672 >0,2816 (valid), st 4 : (satisfaction) $0,614>0,2816$ (valid) meanwhile for testing the reliability of all data obtained reliable.

\section{REFERENCES}

[1] M. Hidayat and S. Rohman, "APLIKASI DAKWAH BERBASIS ANDROID MENGGUNAKAN METODE USER CENTERED DESIGN (UCD)," J. Penelit. dan Pengabdi. Kpd. Masy. UNSIQ, 2018, doi: 10.32699/ppkm.v5i3.484.

[2] T. R. A. Siddiqi, "Desain Aplikasi Sistem Informasi Kajian Islam Berbasis Android," Univ. Islam Indones., 2018.

[3] M. Rudi Sanjaya, "REKAYASA MODEL PERANGKAT LUNAK GEOGRAFIS PARIWISATA UNTUK PENCARIAN WISATA TEMPAT UMUM DAN TEMPAT TRANSPORTASI KOTA PALEMBANG," Digit. Teknol. Inf., 2018, doi: https://doi.org/10.32502/digital.v1i1.931.

[4] Y. D. Triyanti, "Aplikasi android untuk pencarian lokasi tempat ibadah di wilayah bekasi," Pros. Semin. Ilm. Nas. Komput. dan Sist. Intelijen (KOMMIT 2014), 2014.

[5] J. I. Sinaga, M. Mesran, and E. Buulo, "Aplikasi Mobile Pencarian Kata Pada Arti Ayat Al-Qur ', an Berbasis Android Menggunakan ...," J. INFOTEK, 2016.

[6] R. T. Jurnal, "APLIKASI PENCARIAN USTADZ UNTUK WILAYAH DKI JAKARTA MENGGUNAKAN ALGORITMA HAVERSINE FORMULA BERBASIS ANDROID," Petir, 2019, doi: 10.33322/petir.v9i2.174.

[7] N. Purwandari and M. Ziveria, "Aplikasi Katalog Perpustakaan Kalbis Institute Berbasis Android," Pros. Semin. Nas. Pendidik. Tek. Inform., 2018.

[8] Suendri, "Implementasi Diagram UML (Unified Modelling Language) Pada Perancangan Sistem (Studi Kasus: UIN Sumatera Utara Medan)," J. Ilmu Komput. dan Inform., 2018.

[9] M. S. Hartawan, "Analisa user interface untuk meningkatkan user experience menggunakan usability testing pada aplikasi android pemesanan test drive mobil," J. Teknol. Inf. ESIT Vol. XIV, 2019.

[10] M. Shalahuddin dan Rosa A.S, "Rekayasa Perangkat Lunak dan Berorientasi Objek," semanTIK, 2016, doi: 10.1249/MSS.0b013e3181946lc2. 